\title{
KINERJA KARYAWAN DILIHAT DARI KEPEMIMPINAN, DUKUNGAN PERUSAHAAN DAN PRAKTIK BEKERJA DARI RUMAH
}

\author{
${ }^{a} A$ nita Maharani, bianthy Kusardi, ' ${ }^{\text {bR }}$ Melanie Ayu Shinta Devi \\ abc Universitas Bina Nusantara \\ anita.maharani@binus.edu
}

\author{
\begin{tabular}{l|l|l} 
Received : September & Accepted : October & Published: December
\end{tabular}
}

\begin{abstract}
ABSTRAK
Penelitian ini memiliki tujuan untuk melihat hal-hal yang mempengaruhi kinerja karyawan yakni kepemimpinan, work from home sebagai pemoderasi dan dan dukungan perusahaan sebagai mediasi. Literatur yang digunakan dalam membangun model penelitian ini antara lain yang berkaitan dengan kepemimpinan, kemudian untuk kinerja karyawan adalah konsep yang berkaitan dengan manajemen kinerja, selanjutnya untuk work from home digunakan konsep flexible working arrangement dan terakhir dukungan perusahaan yang juga mengacu pada konsep dukungan perusahaan. Metode penelitian dengan pendekatan kuantitatif, dengan pengambilan sampel secara acak pada responden yang bekerja di perusahaan non esensial di Jakarta, kemudian diolah menggunakan pendekatan variance based structural equation modelling. Hasil yang diperoleh menunjukkan bahwa kepemimpinan mempengaruhi kinerja karyawan di perusahaan non esensial, kemudian tidak didapat bukti bahwa dukungan perusahaan tidak terbukti mempengaruhi kinerja karyawan di perusahaan non esensial, selain itu work from home sebagai pemoderasi dan dukungan perusahaan tidak terbukti sebagai pemediasi kepemimpinan dan kinerja karyawan. Implikasi dari hasil penelitian ini adalah pada perusahaan non esensial perlu mencari formula selain dukungan perusahaan dan praktik work from home dalam hal mendorong kinerja karyawan, namun demikian kepemimpinan memiliki pengaruh terhadap kinerja khususnya di perusahaan non esensial, sehingga sisi kepemimpinan dianggap perlu untuk dioptimalkan.
\end{abstract}

Kata Kunci: Kepemimpinan, Kinerja, Work From Home, Dukungan Perusahaan, Pandemi

\section{ABSTRACT}

This study will look at leadership, work from home as a moderator, and company support as a mediator, all of which have an impact on employee performance. The literature utilized to develop this research model is focused on leadership, followed by a concept connected to performance management for employee performance, flexible working arrangements for work from home, and finally corporate support, which also refers to the notion of business assistance. The study used a quantitative methodology, with respondents selected at random from non-essential enterprises in Jakarta, and data processed using a variance-based structural equation modeling method. The findings show that leadership has an impact on employee performance in non-essential businesses; however, there is no evidence that company support has an impact on employee performance in non-essential businesses, and work from home as a moderator and company support have not been proven to mediate leadership and employee performance.

Keywords: Leadership, Performance, Work From Home, Organizational Support, Pandemic 


\section{PENDAHULUAN}

Pada tahun 2020 seluruh dunia diguncangkan oleh pandemi Corona Virus Disease (Covid-19), hal ini kemudian ditanggapi dengan sikap pemerintah, yang mengeluarkan peraturan tentang penyesuaian sistem kerja pegawai dalam upaya pencegahan penyebaran Covid-19. Fenomena ini juga memicu banyaknya studi yang mencoba mengangkat kaitan antara Covid-19 dengan kehidupan, diantaranya kehidupan kerja. Berdasarkan scholar.google.co.id, ada lebih dari 1000.000 hasil luaran penelitian yang berkaitan dengan fenomena, diantara 1000.000 hasil luaran tersebut ada lebih dari 40.000 hasil luaran yang mengangkat mengenai faktor-faktor yang mempengaruhi kinerja karyawan, seperti studi Narayamurthy et al (2021), Wolor et al (2020) dan lain sebagainya.

Untuk Indonesia sendiri, kaitan antara pandemic Covid-19 dan kehidupan disoroti oleh sejumlah peneliti. Dari sejumlah penelitian yang ada dan muncul di tahun 2020an banyak mengulas pengaruh dari penetapan peraturan yang dikeluarkan oleh pemerintah kemudian yang diterjemahkan oleh perusahaan dalam bentuk praktik jam kerja dan lokasi bekerja, yang kemudian dikenal dengan istilah work from home. Purwanto et al (2020) menulis tentang dampak yang ditimbulkan oleh praktik kerja work from home terhadap kinerja. Hal serupa juga dilakukan oleh Setyawan et al (2020), Irawanto et al (2020), Darmawan et al (2020) yang merupakan Sebagian dari banyaknya peneliti yang menaruh perhatian pada tema mode bekerja di masa pandemic.

Ditinjau dari konsepnya, work from home sebenarnya bukan konsep baru yang dipraktikkan di tempat kerja. Work from home atau lebih dikenal dengan telecommuting atau teleworking pertama kali diperkenalkan oleh Niles JM pada tahun 1973 (Nilles, 1988). Telecommuting mengacu pada substitusi sebagian atau total telekomunikasi, dengan atau tanpa bantuan komputer. Telecommuting mencakup semua penggantian teknologi telekomunikasi dan informasi untuk pekerjaan.

Di sisi lain, kinerja adalah hasil kerja dalam kuantitas yang dicapai oleh seorang karyawan dalam menjalankan tugasnya sesuai dengan tanggung jawabnya. Sebagian besar manajer percaya kinerja yang baik berarti melakukannya dengan baik pada kinerja tugas. Kriteria mengevaluasi kinerja karyawan yang populer dalam tiga kriteria, yaitu hasil tugas individu, perilaku, dan sifat. Faktor keberhasilan kritis dalam teleworking adalah dukungan manajemen, komunikasi, dan kepercayaan. Dukungan manajemen meliputi dukungan organisasi, kepemimpinan, dan ruang kerja terkelola (Kowalski \& Swanson, 2005). Dengan demikian dapat diketahui bahwa kinerja karyawan dapat disebabkan oleh karena adanya dukungan perusahaan.

Pemimpin organisasi, manajer, dan pengawas juga harus mempertimbangkan untuk menggunakan strategi untuk mengatasi tantangan teleworking (Burbach \& Day, 2012). Dengan kata lain, kepemimpinan adalah proses di mana seseorang dapat menjadi pemimpin melalui kegiatan yang berkesinambungan sehingga dapat mempengaruhi siapa yang dipimpin dalam rangka mencapai tujuan organisasi. Meskipun kepemimpinan umumnya didefinisikan sebagai 'seni memastikan orang lain memiliki' keinginan untuk berusaha mencapai tujuan bersama' (Kouzes \& Posner, 1995), kepemimpinan tidak dapat dianggap berhasil dan tidak penting dalam konteks organisasi jika hasil yang diperoleh tidak sesuai dengan tujuan bersama (Koech \& Namusonge, 2012).

Kepemimpinan adalah aspek penting karena biasanya memungkinkan karyawan organisasi untuk bekerja secara efisien dan efektif (Agarwal, 2020). Menurut Cascio (2000) di kantor virtual seperti telework atau work from home, tantangan bagi para pemimpin adalah menetapkan dan menegakkan aturan dasar untuk komunikasi yang komprehensif dan proses manajemen kinerja. Menanggapi hal tersebut, sebagai pemimpin ada urgensi untuk dapat beradaptasi ketika model bekerja berubah menjadi mode work from home, yakni mempelajari cara melakukan rapat yang efektif dan menyeimbangkan email, pesan suara, konferensi video, dan komunikasi tatap muka. Kemudian tantangan berikutnya bagi para pemimpin adalah merancang manajemen kinerja bagi karyawan, dan hal ini dapat dimulai dengan cara mendefinisikan yang dimaksud dengan kinerja, mendorong dan memfasilitasi hal-hal yang dianggap mendukung terwujudnya kinerja yang ideal (Cascio, 2000). 
Untuk situasi saat pada pandemi, tidak banyak manajer yang percaya bahwa kehadiran dan jam kerja yang panjang sangat penting untuk kemajuan karir dalam organisasi. Ada data penting yang ditemukan oleh peneliti, yakni sebelum lockdown, 57,3\% manajer percaya bahwa karyawan perlu hadir secara fisik di tempat kerja untuk maju, menurun menjadi $37,5 \%$ sejak kebijakan lockdown (Chung, Seo, Forbes, \& Birkett, 2020). Meskipun dianggap bahwa kebijakan work from home sebagai solusi pada saat pemerintah mengeluarkan kebijakan lockdown, dalam studi yang dilakukan oleh Chung et al (2020) diketahui bahwa tidak semua manajer merasa sepakat mengenai dampak positif work from home terhadap kinerja dengan kata lain, dukungan perusahaan untuk menciptakan kondisi yang ideal atas praktik work from home dapat mempengaruhi kinerja karyawan. Hal ini juga menjadi menarik seiring dengan temuan dari Daraba et al (2020) yang menemukan bahwa kepemimpinan mempengaruhi kinerja karyawan pada masa pelaksanaan praktik work from home. Dibanding dari penelitian sebelumnya, yang menguji fenomena work from home dari sisi kepemimpinan sebagaimana dalam studi Daraba et al (2020) atau kaitan antara dukungan perusahaan terhadap kinerja sebagaimana yang pernah dilakukan oleh Bryne et al (2008), penelitian ini akan mencoba melihat keterkaitan antara dukungan perusahaan, kepemimpinan terhadap kinerja karyawan dan melihat kemungkinan peranan praktik work from home diantara dinamika tersebut.

Indonesia, mengalami sejumlah dinamika pada masa pandemic Covid-19, diantaranya pemerintah menerapkan sejumlah kebijakan, yang bertujuan untuk mengurangi kenaikan jumlah masyarakat yang terkena virus Covid-19, antara lainnya dengan pembatasan sosial, yang selanjutnya berkembang dengan sejumlah istilah. Ditahun 2020-2021, perusahaan yang paling terdampak adalah perusahaan yang bergerak di sektor non-esensial. Perusahaanperusahaan yang bergerak di sektor non-esensial didorong untuk mengoperasikan bisnis dari "rumah" karyawan atau yang dikenal dengan istilah work-from home yang menggantikan mekanisme bekerja dari kantor atau work from office. Di sisi lain, perihal kebijakan work-from home untuk perusahaan non esensial pernah diteliti oleh Song et al (2021) yang menemukan bahwa kebijakan work-from home untuk perusahaan non esensial memiliki dampak yang baik untuk menahan laju penularan virus Covid-19. Dalam kaitannya dengan paragraph sebelumnya, idealnya perusahaan yang bergerak di non esensial juga perlu memperhatikan keterkaitan antara dukungan perusahaan, dan kepemimpinan terhadap kinerja karyawannya.

\section{KAJIAN LITERATUR}

\section{Konsep Kepemimpinan}

Dalam perkembangan keilmuannya, konsep kepemimpinan mengalami evolusi definisi dari waktu ke waktu, di abad ke-21 konsep kepemimpinan yang berkembang adalah kepemimpinan otentik, kepemimpinan spiritual, kepemimpinan yang melayani dan kepemimpinan adaptif (Rost, 1991). Kemudian, Northouse (2016) menjelaskan definisi kepemimpinan adalah proses yang terjadi pada seorang individu dalam rangka mempengaruhi suatu kelompok atau individu lainnya dalam tujuan mencapai tujuan yang sama. Menariknya dalam studi lampau yang dilakukan oleh Kotter (1990) ditemukan bahwa kepemimpinan adalah suatu hal yang unik karena menekankan pada proses interaksi antara pemimpin dan pengikutnya. Dalam penelitian ini, kepemimpinan adalah konteks dan tidak secara khusus mengacu pada tipe kepemimpinan tertentu.

\section{Konsep Dukungan Perusahaan}

Dukungan perusahaan diperkenalkan oleh Eisenberger et al (1986) sebagai konsep yang menggambarkan sesuatu yang dirasakan oleh karyawan terhadap perusahaannya, yakni tentang sejauhmana perusahaan memberikan pengakuan terhadap kesejahteraan karyawan dan memberikan penghargaan. Kemudian Schemerhon (2010) memandang dukungan perusahaan lebih dari sekedar kontrak psikologis dari perusahaan ke karyawannya, dengan kata lain hal ini berkaitan dengan pemenuhan kebutuhan yang tidak sekedar psikologis, dari perusahaan ke karyawannya. Dengan demikian, dalam penelitian ini akan 
mengangkat dukungan perusahaan yang merupakan upaya perusahaan untuk mencukupi kebutuhan karyawan saat bekerja di perusahaan.

\section{Konsep Kinerja Karyawan}

Kinerja karyawan adalah sebuah konsep yang biasa digunakan sebagai gambaran hasil kerja karyawan selama satu waktu tertentu. Dalam Shahzadi et al (2014) disebutkan bahwa kinerja karyawan melihat mutu, dan jumlat luaran, absesi di tempat serta hal-hal lainnya yang mendukung kebutuhan tersebut. Wright et al (2019) menyatakan bahwa kinerja karyawan dianggap sebagai sumber keunggulan strategis perusahaan terutama untuk tetap bertahan di lingkungan bisnis yang kompetitif.

\section{Definisi Work from Home dan Dinamikanya di Masa Pandemi Covid-19}

Studi yang mengangkat praktik work from home sudah ada sejak sebelum pandemic Covid-19. Dalam temuan peneliti diketahui salah satu hasil studi yang pernah mengangkat tema work from home dihasilkan oleh Shamir et al (1985) yang mengaitkan teknologi telekomunikasi yang mendukung praktik work from home, dan menariknya pada tahun 1980an sudah muncul kekhawatiran dari peneliti yang melihat potensi permasalahan yang ditimbulkan dari praktik work from home ini. Sehingga tidak mengherankan ketika praktik work from home diuji dengan variabel lainnya baik sebagai variabel yang mempengaruhi maupun variabel yang dianggap memoderasi pengaruh sebab akibat.

\section{Dinamika Antara Variabel Penelitian}

Bass et al (2000) menyebutkan bahwa sejumlah perasaan akan muncul dari bawahan kepada pemimpinnya, diantaranya adalah rasa percaya dan rasa hormat, yang pada akhirnya akan memunculkan sukarela di kalangan bawahan yang akan berguna untuk mencapai citacita organisasi atau yang lebih dikenal dengan tujuan organisasi. Di sisi lain, Robbins (2001) menegaskan bahwa wujud orang yang memiliki kecenderungan kepemimpinan transformasional adalah siapa pun yang dapat memberikan inspirasi kepada pengikutnya, dalam rangka untuk mengubah hidup dan mampu mencapai tujuan yang lebih besar. Luthans (2005) kemudian memunculkan pandangan bahwa pemimpin transformative seharusnya mampu melakukan perubahan di kalangan pengikutnya. Sejumlah cara yang menurut Luthans (2005) dapat dilakukan adalah dengan mendorong munculnya semangat di kalangan pengikut, dan memberikan motivasi kepada pengikut untuk melakukan yang terbaik dalam rangka mencapai target organisasi, dan yang terpenting adalah, pengikut bersukarela untuk melakukan perubahan.

Di sisi lain, kinerja dapat dipahami sebagai perilaku yang ditunjukkan oleh karyawan dengan tujuan agar tujuan perusahaan tercapai (Armstrong \& Taylor, 2014). Selain itu, kinerja juga dipahami sebagai proses, yakni sesuatu yang terjadi dalam rangka mencapat suatu tujuan, dan menariknya menurut Luthans (2005) kinerja dapat berupa suatu hal yang dilakukan dan sebaliknya. Kemudian, mengukur kinerja karyawan di dalam organisasi memerlukan sejumlah pengukuran. Menurut Babin dan Boles (1998) kinerja dalam praktiknya dapat dipengaruhi oleh konflik peran, dan tekanan dalam pekerjaan (Babin \& Boles, 1998). Menurut Bernardin dan Russel (1993), kualitas kerja, kuantitas kerja, biaya yang dapat ditekan serta keterikatan antara personal menjadi kriteria kinerja, hal ini juga ditekankan oleh Mathis dan Jackson (2002) hanya bedanya ada unsur kehadiran dan loyalitas yang dianggap sebagai kriteria kinerja. Oleh karena itu, kepemimpinan di dalam organisasi bisnis sangat penting dan krusial (Asbari et al., 2019). Lebih lanjut, Rozi et al (2020) menemukan bahwa kepemimpinan mempengaruhi kinerja karyawan dengan adanya hubungan yang kuat dan positif.

\section{H1: kepemimpinan memberikan pengaruh positif terhadap kinerja karyawan}

Pengaturan kerja yang fleksibel salah satunya ditulis oleh Hill et al., (2008) yang mengangkat tema ini sebagai kapasitas pekerja dalam rangka menyelesaikan keputusan dan berdampak terhadap kapan, di mana, dan untuk berapa lama karyawan akan berpartisipasi dalam tugas pekerjaanya. Masuda, et al., (2012) bahkan menamai adanya empat jenis 
pengaturan kerja yang fleksibel, antara lainnya waktu fleksibel, waktu kerja yang terkompres, telecommuting (juga dikenal sebagai flexplace), dan pekerjaan paruh waktu.

Sebelum terjadi pandemic, pandangan manajer tentang bekerja dalam mode yang fleksibel adalah suatu hal yang sulit diterima. Dalam studi yang dilakukan oleh Bewley et al (2013) disebutkan bahwa ada sejumlah alasan yang dimiliki manajer ketika tidak mengizinkan karyawan untuk bekerja dari rumah, alasan paling umum yang diberikan adalah sifat pekerjaan tidak mungkin bagi karyawan untuk bekerja dari rumah dalam peran ini. Namun demikian, dalam perkembangannya, Mungania et al. (2016) menemukan bahwa dukungan perusahaan dalam hal pengaturan kerja fleksibel dapat mendorong kinerja karyawan lebih baik. Dengan kata lain, fleksibilitas dapat digunakan untuk memenuhi tujuan bisnis dan memfasilitasi efektivitas karyawan di tempat kerja. Mode kerja fleksibel memiliki hubungan yang positif dan bahkan solid terhadap kinerja karyawan.

\section{H2: Dukungan perusahaan memberikan pengaruh positif terhadap kinerja karyawan}

Kepemimpinan, memberikan pengaruh terhadap kinerja karyawan. Logika ini berkaitan dengan kinerja karyawan yang tinggi tidak mungkin tercapai tanpa keterlibatan pemimpinnya. Hasil studi Muizu et al (2019) menunjukkan bahwa kinerja karyawan dipengaruhi oleh kepemimpinan. Selain Muizu et al (2019) masih banyak studi lainnya yang menyebutkan adanya hubungan yang tidak terpisahkan antara kepemimpinan dengan kinerja karyawan, sehingga seakan-akan tema yang mengangkat terkait kedua hal ini sudahlah merupakah hal yang umum dan dapat diterima. Oleh karena itu, sudut pandang kaitan antara kedua hal ini kemudian dikembangkan dengan mengaitkan sejumlah faktor, bahwa kepemimpinan tidak dapat mempengaruhi kinerja karyawan secara langsung kecuali adanya keterlibatan faktor-faktor lainnya. Seperti pada studi Wolor et al (2020) yang mengangkat keterkaitan antara kepemimpinan, dan kinerja dengan melibatkan keefektifan pelatihan dan hadirnya keseimbangan kerja. Namun dari sejumlah penelitian yang ditemukan lainnya, diketahui bahwa dukungan perusahaan adalah hal yang tidak terlepaskan dengan kaitan antara kepemimpinan dan kinerja karyawan, dan menariknya tanpa pandemic sekalipun keterkaitan antara kepemimpinan, kinerja karyawan dan dukungan perusahaan sebagai pemediasi sudah diuji (Erdogan et al, 2007; DeConinck et al, 2018; Casimir et al, 2014, Astuty et al, 2020)

\section{H3: Kepemimpinan mempengaruhi kinerja karyawan dengan dukungan perusahaan sebagai pemediasi}

Dukungan organisasi yang dirasakan dianggap sebagai sumber daya yang mampu mempengaruhi kinerja secara positif (Bryne, et al, 2008). Menurut teori dukungan organisasi, dukungan organisasi mencerminkan sejauh mana karyawan percaya bahwa organisasi tempat bekerjanya menghargai kontribusi karyawan dan peduli tentang kesejahteraan karyawan (Guan et al, 2014). Bila work from home dipraktikkan di dalam organisasi, diasumsikan ini dapat memoderasi pengaruh dukungan perusahaan terhadap kinerja karyawan. Sejumlah penelitian menunjukkan nilai tambah dan kerugian terkait dengan pekerjaan yang dilakukan dari rumah.

\section{H4: Praktik kerja work from home akan memoderasi pengaruh dukungan perusahaan terhadap kinerja karyawan}

Berikut ini adalah model penelitian yang diajukan. 


\section{Gambar 1.Model Penelitian}

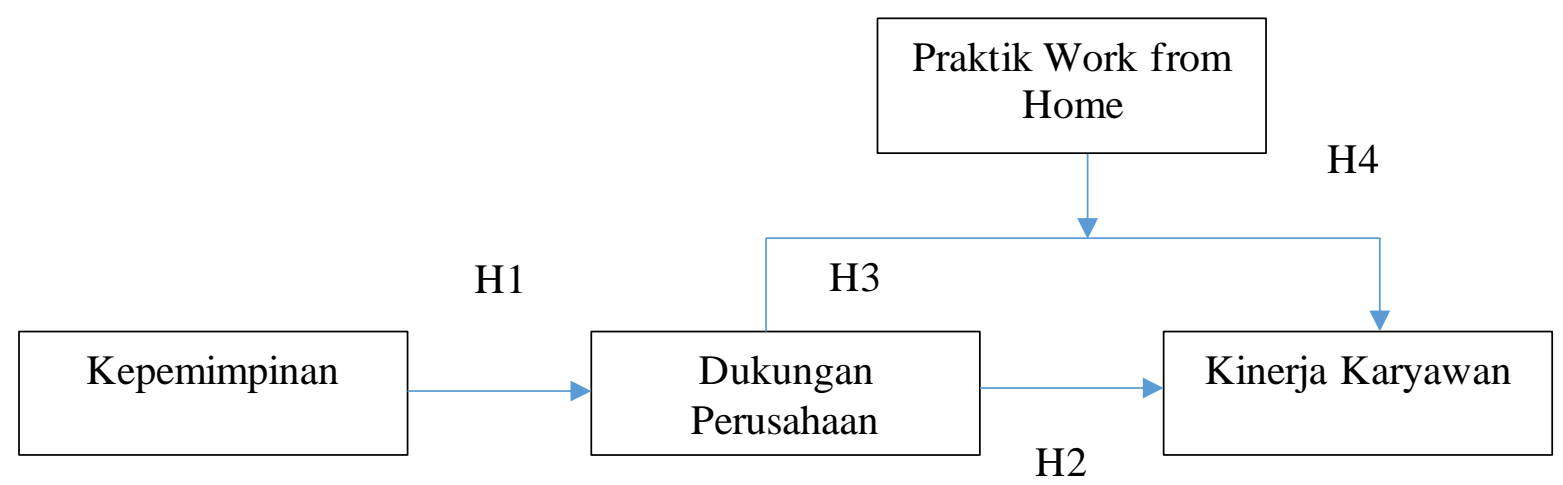

\section{METODE}

Penelitian ini mengadopsi pendekatan kuantitatif. Survey disebar ke beberapa jenis perusahaan jasa yaitu perhotelan, perbankan, servis telekomunikasi dan ditargetkan dapat memperoleh > 100 orang responden, agar dapat mewakilkan hasil yang berbeda dari berbagai macam latar belakang responden. Dari hasil penyebaran survey selama satu bulan di bulan Agustus 2021 melalui google form https://forms.gle/QSKECbeARjWvCrhR8. Tautan pertanyaan akan berisi kuisioner berkaitan dengan variabel yang diuji.

Pada bagian ini akan dipaparkan mengenai hasil pengumpulan data dan analisisnya. Data yang telah dikumpulkan dari responden dalam jangka waktu 3 hari, kemudian diolah, dan peneliti tidak melakukan perubahan atau intervensi sehingga ada potensi data termanipulasi (Non Contrived setting). Sebagai gambaran situasi di pandemic Covid-19. Sejumlah organisasi penyedia jasa yang dikategorikan sebagai non esensial tetap harus menjalankan pekerjaan walaupun dari rumah atau yang kemudian dikenal dengan istilah Work From Home. Kondisi ini berlangsung terutama sejak pemerintah mengeluarkan kebijakan PSBB ( Pembatasan Sosial Berskala Besar) yang dijalankan di Jakarta pada bulan April 2020.

Dalam penelitian ini, target populasi adalah para pekerja penyedia jasa seperti perbankan, konsultan, perusahaan komunikasi. Total jumlah populasi perusahaan di Jakarta yang termasuk 10 sektor swasta dan kantor pemerintahan tidak diketahui secara tepat, begitu juga jumlah karyawan yang bekerja di sektor tersebut, namun demikian responden yang terlibat dalam penelitian ini merepresentasikan fenomena yang terjadi di lingkungan perusahaan non esensial. Sehingga, sampel dipilih secara acak dengan menyebarkan sebanyak-banyaknya survey dengan menyebutkan pertanyaan saringan.

Dari sisi item pernyataan, penelitian ini mengadopsi 1 hingga 6 (dari sangat tidak setuju ke sangat setuju). Setelah dilakukan pengumpulan data, Langkah berikutnya adalah peneliti melakukan pengujian reliabilitas dan validitas dengan SmartPLS, dengan melihat nilai Composite Reliability dan Average Variance Explained, kemudian untuk validitasnya peneliti melihat hasil Discriminant Validity yang ditunjukkan melalui tabel Fornell-Larcker. Setelah seluruh item terbukti memenuhi kriteria, Langkah berikutnya adalah melakukan pengecekan terhadap nilai R-Square yang bertujuan untuk melihat potensi model yang diajukan dengan kondisi nyata di lapangan. Terakhir pengujian dengan bootstrapping ( $N$ : 5000) untuk memprediksi model dengan melihat P-Values dan t-statistics.

Lebih lengkapnya dijelaskan sebagai berikut untuk tahapan pengujian. Tahap-tahap tersebut adalah melalui penilaian outer model, kemudian mengevaluasi reliability dan average variance extracted, selanjutnya discriminant validity dan terakhir menguji model structural. 


\section{HASIL DAN PEMBAHASAN}

Dari data yang masuk memberikan respon diperoleh 165 berkas respon survey, bekerja di industry jasa, yaitu perhotelan, restoran, telekomunikasi dengan kisaran umur 2555 tahun. Dari level staff / entry sampai manager.

Untuk menguji keandalan butir-butir pernyataan penelitian ini, peneliti melakukan prosedur pengujian outer model dan melihat nilai Composite Reliability dan Average Variance Extracted. Pada uji yang pertama, diketahui satu variabel tidak memenuhi kaidah yang seharusnya, sebagai berikut

Tabel 2. Construct Reliability dan Validitas (1)

\begin{tabular}{lcccc}
\hline & $\begin{array}{c}\text { Cronbach' } \\
\text { s Alpha }\end{array}$ & rho_A & $\begin{array}{c}\text { Composite } \\
\text { Reliability }\end{array}$ & $\begin{array}{c}\text { Average } \\
\text { Variance } \\
\text { Extracted } \\
\text { (AVE) }\end{array}$ \\
\hline $\begin{array}{l}\text { Dukungan } \\
\text { Perusahaan }\end{array}$ & 0,796 & 0,811 & 0,842 & 0,537 \\
\hline Kepemimpinan & 0,926 & 0,938 & 0,944 & 0,772 \\
\hline Kinerja Karyawan & 0,382 & 0,607 & 0,084 & 0,409 \\
\hline Work From Home & 0,871 & 0,886 & 0,905 & 0,656 \\
\hline
\end{tabular}

Kemudian, peneliti melakukan pengecekan pada outer loading di setiap variabel, dan mendapati ada item-item yang tidak memenuhi kaidah $(<0,6)$ yakni pada item KIN_1 dan KIN_2 yang keduanya adalah item untuk mengukur variabel kinerja karyawan. Setelah kedua item tersebut tidak digunakan nilai Composite Reliability dan Average Variance Extracted pun mengalami perubahan, sebagai berikut

Tabel 3. Construct Reliability dan Validitas (2)

\begin{tabular}{|c|c|c|c|c|}
\hline & $\begin{array}{l}\text { Cronbach's } \\
\text { Alpha }\end{array}$ & rho_A & $\begin{array}{l}\text { Composite } \\
\text { Reliability }\end{array}$ & $\begin{array}{l}\text { Average } \\
\text { Variance } \\
\text { Extracted } \\
\text { (AVE) }\end{array}$ \\
\hline $\begin{array}{l}\text { Dukungan } \\
\text { Perusahaan }\end{array}$ & 0,796 & 0,843 & 0,855 & 0,554 \\
\hline Kepemimpinan & 0,926 & 0,945 & 0,944 & 0,771 \\
\hline Kinerja Karyawan & 0,744 & 0,688 & 0,810 & 0,602 \\
\hline Work From Home & 0,871 & 0,501 & 0,866 & 0,568 \\
\hline
\end{tabular}

Dari tabel 3., diketahui bahwa semua variabel telah terpenuhi untuk kriteria layak (baik dari Composite Reliability maupun Average Variance Extracted), namun demikian, nilai rho_A menunjukkan sebaliknya $(<0,7)$, ada pendapat yang menyebutkan bahwa nilai rho_A merepresentasikan reliabilitas koefisien (Dijkstra dan Henseler, 2015), namun demikian peneliti memutuskan untuk menggunakan CR dan AVE untuk memutuskan bahwa seluruh item memiliki kelayakan untuk diteruskan pada tahap pengujian inner model.

Dari tabel di atas, diketahui bahwa seluruh variabel memiliki item-item yang reliabel $(\mathrm{CR}>0,7)$ dan valid (AVE $>0,5)$. Berikutnya adalah melihat nilai Discriminant Validity melalui tabel berikut ini 
Tabel 3. Fornell-Larcker Criterion

\begin{tabular}{lrrrr}
\hline & $\begin{array}{l}\text { Dukungan } \\
\text { Perusahaan }\end{array}$ & Kepemimpinan & $\begin{array}{l}\text { Kinerja } \\
\text { Karyawan }\end{array}$ & $\begin{array}{l}\text { Work } \\
\text { From } \\
\text { Home }\end{array}$ \\
\hline $\begin{array}{l}\text { Dukungan } \\
\text { Perusahaan }\end{array}$ & 0,745 & & & \\
\hline Kepemimpinan & 0,764 & 0,878 & & \\
\hline Kinerja Karyawan & $-0,364$ & $-0,413$ & 0,776 & \\
\hline Work From Home & $-0,296$ & $-0,300$ & 0,101 & 0,753 \\
\hline
\end{tabular}

Dari tabel di atas, diketahui bahwa variabel penelitian ini memiliki item-item yang memenuhi syarat untuk dianggap valid (dimana garis diagonal lebih besar dari pada kaitan antar variabel) atau dengan kata lain Average Variance Extracted (AVE) memiliki nilai lebih besar dari Latent Variable Correlations yang tergambar dalam garis diagonal tabel 3 di atas. Setelah dianggap layak, selanjutnya peneliti melihat nilai R-Square yang dapat ditemukan pada pengujian PLS Algoritma sebagai berikut.

Tabel 4. R-Square

\begin{tabular}{lcr}
\hline & R Square & \multicolumn{2}{c}{ R Square Adjusted } \\
\hline $\begin{array}{l}\text { Kinerja } \\
\text { Karyawan }\end{array}$ & 0,177 & 0,162 \\
\hline
\end{tabular}

Berdasarkan tabel di atas, diketahui bahwa $\mathrm{R}$ Square model penelitian ini adalah 0,177 atau dengan kata lain, model ini hanya mampu menggambarkan fenomena yang ada di kehidupan organisasi terutama dalam kaitannya dengan kinerja karyawan sebesar $17,7 \%$. Hal ini tentunya menjadi tantangan ketika hipotesis nantinya terbukti, maka peneliti harus dapat mengeksplorasi 82,3 \% faktor lainnya yang dapat mempengaruhi kinerja karyawan terutama pada kasus di perusahaan non esensial.

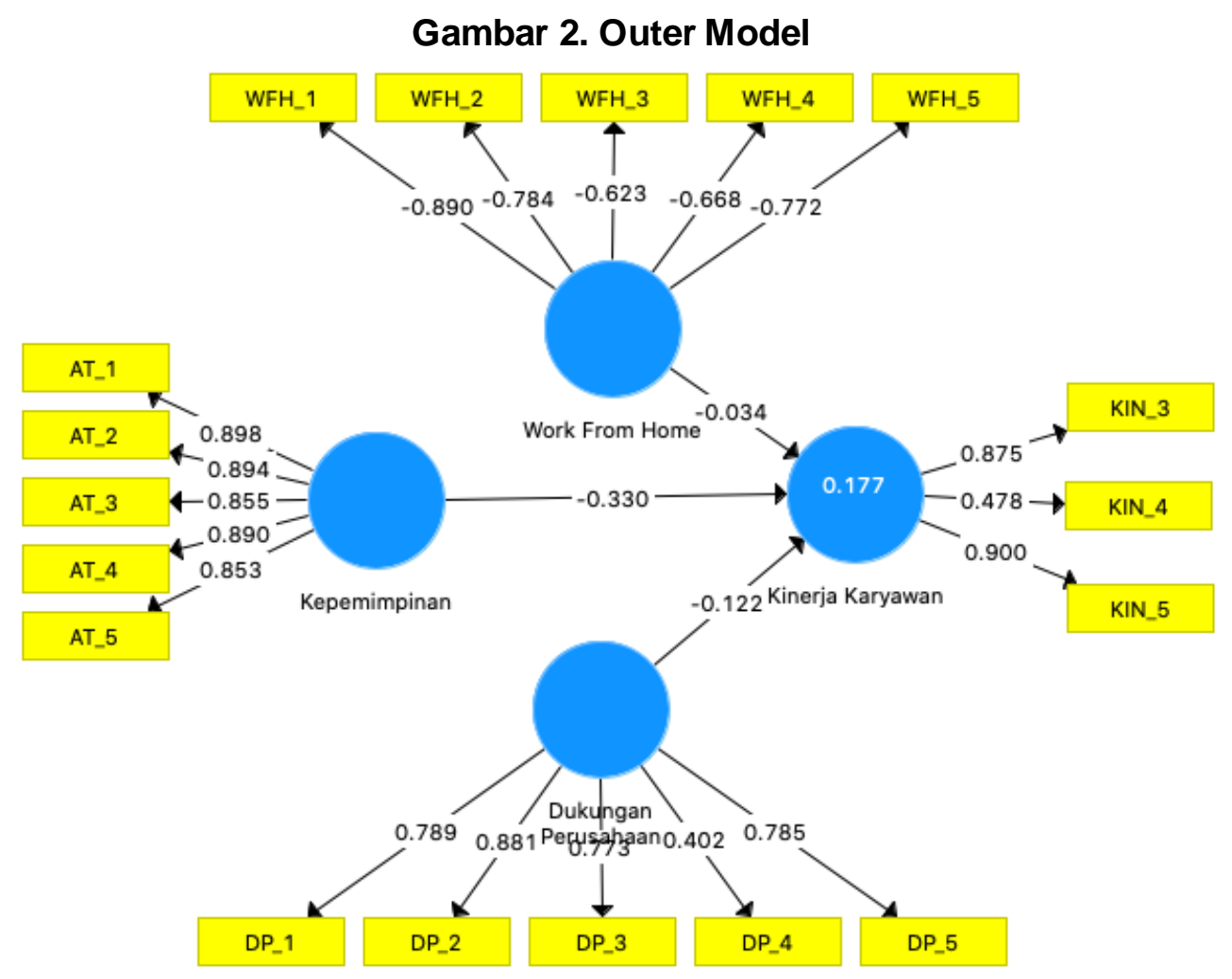


Berikutnya adalah pengujian bootstrapping ( $N$ : 5000) yang ditempuh untuk mengetahui apakah hipotesis yang diajukan terdukung atau sebaliknya. Sebagai berikut

Tabel 5. Path Coefficients dan Specific Indirect Effect

\begin{tabular}{lccccc}
\hline & $\begin{array}{l}\text { Original } \\
\text { Sample } \\
(\mathbf{O})\end{array}$ & $\begin{array}{l}\text { Sample } \\
\text { Mean (M) }\end{array}$ & $\begin{array}{l}\text { Standard } \\
\text { Deviation } \\
\text { (STDEV) }\end{array}$ & $\begin{array}{l}\text { T Statistics } \\
(\mid \mathbf{O} / \text { STDEV|) }\end{array}$ & P Values \\
\hline $\begin{array}{l}\text { Kepemimpinan -> Kinerja } \\
\text { Karyawan }\end{array}$ & $-0,343$ & $-0,338$ & 0,123 & 2,793 & $\mathbf{0 , 0 0 9}$ \\
\hline $\begin{array}{l}\text { Dukungan Perusahaan -> } \\
\text { Kinerja Karyawan }\end{array}$ & $-0,098$ & $-0,107$ & 0,138 & 0,173 & $\mathbf{0 , 4 7 6}$ \\
\hline $\begin{array}{l}\text { Kepemimpinan -> Dukungan } \\
\text { Perusahaan -> Kinerja } \\
\text { Karyawan }\end{array}$ & $-0,075$ & $-0,083$ & 0,108 & 0,697 & $\mathbf{0 , 4 8 6}$ \\
$\begin{array}{l}\text { Dukungan Perusahaan -> } \\
\text { Kinerja Karyawan dengan } \\
\text { Moderasi Praktik Work From } \\
\text { Home }\end{array}$ & 0,103 & 0,090 & 0,064 & 1,606 & $\mathbf{0 , 1 0 8}$ \\
\hline
\end{tabular}

\section{Gambar 3. Inner Model}

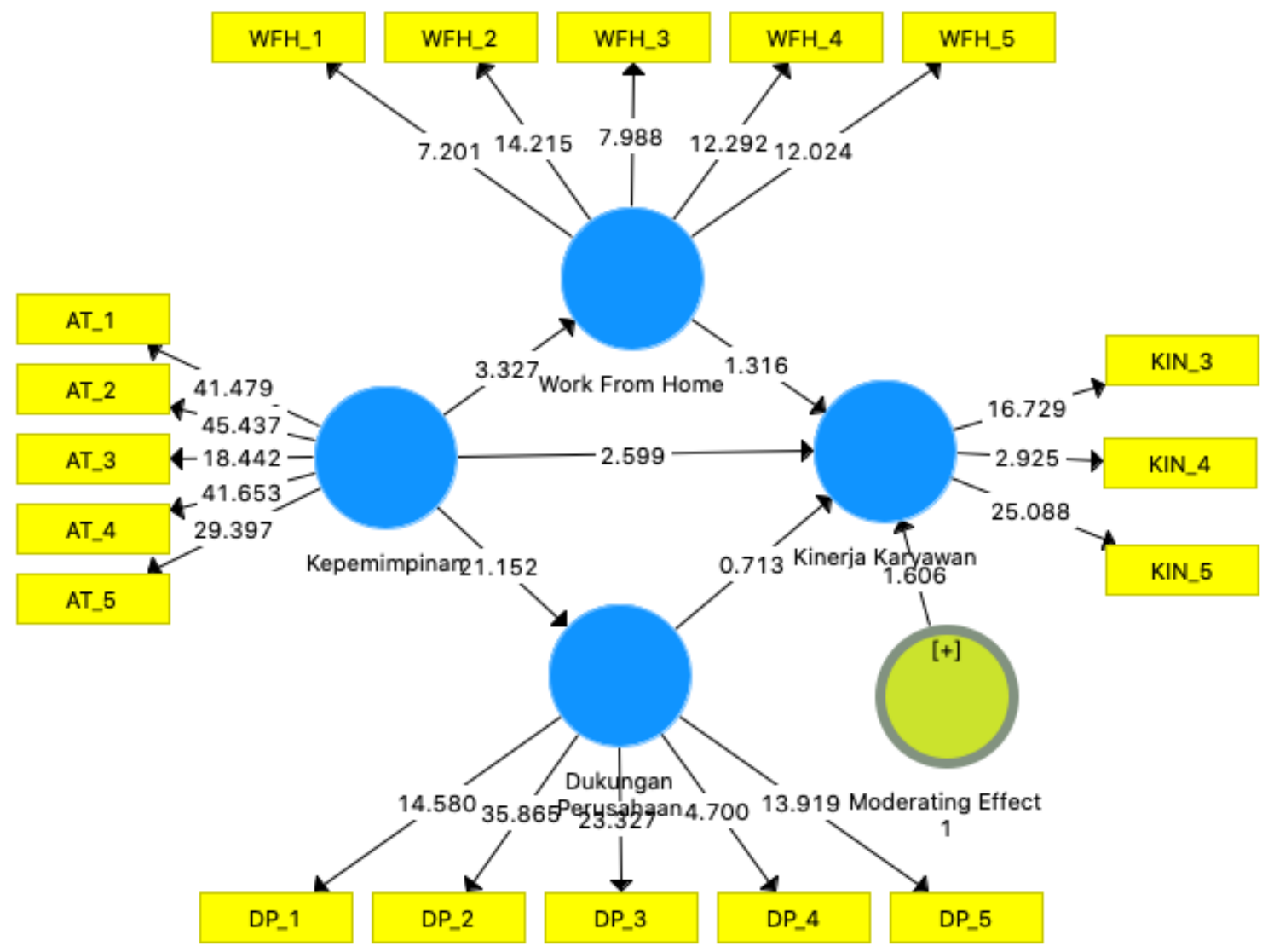

Berdasarkan tabel 5., di atas, peneliti dapat mengetahui bahwa tiga dari empat hipotesis yang diajukan tidak terdukung. Beberapa kemungkinan yang melatarbelakangi tidak terbuktinya hipotesis dapat disebabkan karena item pengukuran, jumlah sampel, atau target responden yang diusulkan. Meskipun hasil penelitian ini menunjukkan bahwa hipotesis yang diajukan tidak terbukti, namun peneliti akan melakukan analisis sehubungan dengan hasil tersebut. 
Pada awalnya peneliti menduga ada fenomena yang berhubungan dengan beberapa literatur yang diacu. Bahwa kepemimpinan mempengaruhi kinerja karyawan terutama pada karyawan yang bekerja di perusahaan non esensial adalah sesuatu hal yang sudah dapat diduga. Secara konseptual, bila berbicara mengenai kepemimpinan akan ada kaitannya dengan kinerja. Idealnya kaitan antara kepemimpinan dan kinerja adalah kaitan antara pemimpin dengan bawahannya, yang saling bekerja sama, dan pemimpin memiliki peran sebagai pendorong bawahan untuk mencapai tujuan tertentu,. Kemudian, ketika berbicara mengenai kinerja berarti berkaitan dengan perilaku pekerja agar target atau misi tercapai (Armstrong \& Taylor, 2014). Dengan demikian, bahkan di perusahaan non esensial sekalipun kinerja karyawan dipengaruhi oleh kepemimpinan. Elemen-elemen kepemimpinan yang dianggap mempengaruhi kinerja karyawan adalah hal-hal yang terkait dengan dukungan moril, contoh nyata untuk penyelesaian masalah, ruang komunikasi dua arah, empati kepada karyawan yang memiliki tekanan secara kejiwaan dan sikap atau keputusan yang fleksible. Seluruh elemen ini dianggap akan mempengaruhi kinerja yang antara lainnya berkaitan dengan perasaan frustasi, tidak mencapai target yang ditentukan dan ketidakmampuan mendapatkan yang dicita-citakan dalam pekerjaan.

Selanjutnya mengenai work from home yang diduga sebagai moderasi, dalam penelitian ini tidak terbukti. Work from homeadalah salah satu implementasi praktik kerja yang fleksibel. Bila dibandingkan dengan pandangan Hill et al (2008) dan Mungania et al (2016) diketahui bahwa pengaturan kerja yang fleksibel yang dapat hal ini direpresentasikan dengan work from home, tidak dianggap sebagai bagian kapasitas pekerja untuk menyelesaikan keputusan yang berdampak kapan, dimana, dan untuk berapa lama karyawan dapat berpartisipasi dalam tugas yang berhubungan dengan bisnis. Elemen dari work from home yang dimaksud antara lainnya berkaitan dengan kemampuan karyawan menyelesaikan pekerjaan kantor di rumah, merasa setuju dengan kebijakan work from home, kemampuan berkonsentrasi saat bekerja dari rumah, merasa telah menjatuhkan pilihan yang tepat dan kemampuan untuk mengatur jam kerja selama berada di rumah. Seluruh elemen work from home ini tidak dapat memperbesar pengaruh dukungan perusahaan terhadap kinerja.

Hasil yang serupa juga didapatkan dari uji tentang kontribusi dukungan perusahaan sebagai pemediasi, yang dalam penelitian ini tidak terbukti. Guan et al (2014) menduga bahwa dukungan perusahaan memang memberikan pengaruh terhadap kinerja, dan Shanock et al (2014) berpendapat kepemimpinan mempengaruhi dukungan perusahaan. Hasil penelitian ini bertolak belakang dengan pandangan para ahli tersebut terutama di kalangan responden yang bekerja di perusahaan non esensial. Elemen dukungan perusahaan yang dimaksud berkaitan dengan kepedulian perusahaan terhadap kesejahteraan karyawan, bantuan perusahaan kepada karyawan dalam hal bekerja dan permintaan karyawan, perusahaan memberikan toleransi terhadap pekerjaan yang tertunda penyelesaiannya dan perusahaan memberikan rekognisi terhadap hasil jerih payah karyawan.

\section{SIMPULAN}

Kesimpulan yang dapat diambil dari penelitian ini adalah, kepemimpinan di perusahaan non esensial mempengaruhi kinerja karyawan selama pandemi Covid-19. Menariknya, praktik work from home yang diduga sebagai moderasi juga tidak terbukti dan begitupun dengan dukungan perusahaan yang tidak terbukti sebagai pemediasi antara kepemimpinan dan kinerja karyawan. Berdasarkan hasil tersebut, peneliti mendorong adanya upaya eksplorasi terkait dengan faktor-faktor yang mempengaruhi kinerja karyawan, selain kepemimpinan dan dukungan perusahaan. Penelitian ini bertujuan untuk mengukur faktorfaktor seperti kepemimpinan, dukungan perusahaan dan work-from home terhadap kinerja karyawan di perusahaan yang bergerak di sektor non esensial. Latar belakangan penelitian berusaha untuk menggambarkan fenomena yang muncul sehingga dianggap menarik untuk diangkat menjadi tema penelitian, namun demikian, peneliti menyadari adanya keterbatasan. Keterbatasan dari penelitian ini adalah representasi dari model penelitian ini yang hanya bisa mengilustrasikan kurang dari $50 \%$, oleh karena itu diperlukan eksplorasi lebih mendalam 
mengenai faktor-faktor yang diduga memberikan kontribusi terhadap kinerja karyawan, terutama dapat konteks lingkungan perusahaan non esensial.

\section{REFERENSI}

Agarwal, S. (2020). Leadership Style and Performance of Employees. International Research Journal of Business Studies, 13(1), 1-14. https://doi.org/10.21632/iribs.13.1.1-14

Armstrong, M., \& Taylor, S. (2014). Human Resource Management Practice. Gosport: Ashford Colour Press Ltd

Asbari, M., Purwanto, A., \& Santoso, P. B. (2019). Influence of Leadership, Motivation, Competence, Commitment and Culture on ISO 9001:2015 Performance in Packaging Industry. Scholars Journal of Economics, Business and Management, 6(12), 577-582.

Astuty, I., \& Udin, U. (2020). The Effect Of Perceived Organizational Support And Transformational Leadership On Affective Commitment And Employee Performance. The Journal Of Asian Finance, Economics And Business, 7(10), 401411. Https://Doi.Org/10.13106/Jafeb.2020.Vol7.No10.401

Babin, B. J., \& Boles, J. S. (1998). Employee Behavior in a Service Environment: a Model and Test of Potential Differences between Men and Women. Journal of Marketing, 62(2), 77 91.

Bass, B., \& Avolio, B. (2000). Technical Report, Leader Form, Rater Form, and Scoring Key of MLQ From 5x-Short. New York: Mind Garden, Inc

Bernardin, H., \& Russel, J. (1993). Human Resource Management: an Experimental Approach. Singapore: Mc Graw Hill Companies.

Bewley, Helen \& Wanrooy, Brigid \& Bryson, Alex \& Forth, John \& Freeth, Stephanie \& Stokes, Lucy \& Wood, Stephen. (2013). Employment Relations in the Shadow of Recession.

Findings from the 2011 Workplace Employment Relations Study.

Byrne, Z.S. and Hochwarter, W.A. (2008), "Perceived organizational support and performance: Relationships across levels of organizational cynicism", Journal of Managerial Psychology, Vol. 23 No. 1, pp. 5472. https://doi.org/10.1108/02683940810849666

Burbach, M. E., \& Day, F. C. (2012). Does Organization Sector Matter in Leading Teleworker Teams? A Comparative Case Study. International Journal of Business Research and Development, 3(1), 8-21.

Casimir, Gian; Ng, Yong Ngee Keith; Wang, Karen Yuan; Ooi, Gavin.(2014). The Relationships Amongst Leader-Member Exchange, Perceived Organizational Support, Affective Commitment and In-Role Performance: A Social-Exchange Perspective. Leadership and Organizational Development Journal Vol.35(5).

Daraba, Dahyar; Wirawan, Hilman; Salam, Rudi; Faisal, Muhammad.(2021). Working from Home During the Corona Pandemic: Investigating the Role of Authentic Leadership, Psychological Capital and Gender on Employee Performance. Cogeant Business and Management, 8:1. DOI: 10.1080/23311975.2021.1885573

Darmawan, Eki; Atmojo, Muhammad Eko.(2020). Kebijakan Work From Home Bagi Aparatur Sipil Negara di Masa Pandemi Covid-19. Vol. 1(3). The Journalish

DeConinck, James B.; Moss, Hollye, K; Deconinck, Mary Beth.(2018). The Relationship Between Servant Leadership, Perceived Organizational Support, Performance, and Turnover Among Business to Business Salespeople. Global Journal of Management and Marketing. Vol. 2 (1).

Eisenberger, R., Huntington, R., Hutchison, S., \& Sowa, D. (1986). Perceived organizational support. Journal of applied psychology, 71(3), 500-507. http://dx.doi.org/10.1037/0021-9010.71.3.500

Erdogan, B., \& Enders, J. (2007). Support from the top: Supervisors' perceived organizational support as a moderator of leader-member exchange to satisfaction and performance relationships. Journal of Applied Psychology, 92(2), 321330. https://doi.org/10.1037/0021-9010.92.2.321 
Guan, X., Sun, T., Hou, Y. et al. The relationship between job performance and perceived organizational support in faculty members at Chinese universities: a questionnaire survey. BMC Med Educ 14, 50 (2014). https://doi.org/10.1186/1472-6920-14-50

Hill, E. J., Grzywacz, J. G., Allen, S., Blanchard, V. L., Matz-Costa, C., Shulkin, S., \& PittCatsouphesc, M. (2008). Defining And Conceptualizing Workplace Flexibility. Community Work \& Family, 11, 149-163. https://doi.org/10.1080/13668800802024678

Irawanto, Dodi W., Khusnul R. Novianti, and Kenny Roz. (2021). "Work from Home:Measuring Satisfaction between Work-Life Balance and Work Stress during the COVID-19 Pandemic in Indonesia" Economies 9, no. 3 : 96. https://doi.org/10.3390/economies9030096

Koech, P. M., \& Namusonge, G. S. (2012). The effect of leadership styles on organizational performance at state corporations in Kenya. International Journal of Business and Commerce, 2(1), 1-12.*

Kotter, J.P. (1990). A Force for Change: How Leadership Differsfrom Management. New York: Free Press.

Kouzes, J. M., \& Posner, B. Z. (1995). The leadership challenge. San Francisco, CA: JosseyBass

Luthans, F. (2005). Organizational Behaviour. Boston: McGraw-Hill.

Masuda, A. D., Poelmans, S. A. Y., Allen, T. D., Spector, P. E., \& Moreno-Velazquez, I. (2012). Flexible Work Arrangements Availability And Their Relationship With Work-To-Family Conflict, Job Satisfaction, And Turnover Intentions: A Comparison Of Three Country Clusters. Applied Psychology: An International Review, 61(1), 1-29. https://doi.org/10.1111/j.1464-0597.2011.00453.x

Mathis \& Jackson. (2002). Manajemen Sumber Daya Manusia (Pertama). Jakarta: Salemba Empat.

Muizu, Wa Ode Zusnita; Kaltum, Umi; Sule, Erni T.(2019). Pengaruh Kepemimpinan Terhadap Kinerja Karyawan. Perwira Jurnal Pendidikan Kewirausahaan Indoensia. Vol. 2 No. 1.

Mungania, A. K., Waiganjo, E. W., \& Kihoro, J. M. (2016). Influence of Flexible Work Arrangements on Performance of the Banking Industry in Kenya. International Journal of Academic Research in Business and Social Sciences, 6(7), 159-172. https://doi.org/10.6007/IJARBSS/v6-i7/2238

Narayanamurthy, Gopalakrishnan; Tortorella, Guillherma.(2021). Impact of COVID-19 Outbreak on Employee Performance - Moderating Role of Industry 4.0 Base Technologies. International Journal of Production Economics. Vol. 234, https://doi.org/10.1016/j.jpe.2021.108075

Purwanto, Agus; Asbari, Masduki; Fahlevi, Mochammad; Mufid, Abdul; Agistiawati, Eva; Cahyono, Yoyok; Suryani, Popong.(2020).Impact of Work From Home (WFH) on Indonesia Teachers Performance During the Covid-19 Pandemic: An Exploratory Study,Vol. 29(5), pp 6235-6244. International Journal of Advanced Science and Technology

Robbins, S. P. (2001). Organizational behavior. Prentice Hall, 9th edition.

Rost, J.C.(1991). Leadership for the twenty-first century. New York: Praeger.

Rozi, Achmad; Agustin, Farida; Hindriari, Reni; Rostikawati, Dian; Akbar, Irfan Rizka.(2020).

The Effect of Leadership on Employee Performance at PT. Stella Satindo In Indonesia. Humanis (Humanities, Management and Science Proceedings). Vol.1(1).

Shamis, Boas; Salomon, Ilan.(1985). Work at Home and the Quality of Working Life. Vol 10 (3). Academy of Management Review.

Schermerhorn, J. R. (2010). Introduction to management (10th ed.). Asia: Wiley

Setyawan, Febri Endra Budi; Lestari, Retno.(2020). Challenges of Stay-At-Home Policy Implementation During The Coronavirus (COVID-19) Pandemic in Indonesia, Vol. 8, Jurnal Administrasi Kesehatan Indonesia 
Shahzadi, Irum; Javed, Ayesha; Pirzada, Syed Shahzaib; Nasreen, Shagufta; Khanam, Farida.(2014). Impact of Employee Motivation on Employee Performance. European Journal of Business and Management. Vol. 6 (23). ISSN 2222-1905

Song, Hummy; McKenna, Ryan M; Chen, Angela T.; David, Guy; Smith-Mclallen, Aaron.(2021).The Impact of the Non-Essential Business Closure Policy on Covid-19 Infection Rates. NBER Working Paper Series. National Bureau of Economic Research.

Wright, P.M. and Snell, S.A. (1998), "Toward a unifying framework for exploring fit and flexibility in strategic human resource management", Academy of Management Review, Vol. 23 No. 4, pp. 756-772.

Wolor, C. W., Solikhah, S., Fidhyallah, N. F., \& Lestari, D. P. (2020). Effectiveness Of ETraining, E-Leadership, And Work Life Balance On Employee Performance During Covid-19. The Journal Of Asian Finance, Economics And Business, 7(10), 443-450. Https://Doi.Org/10.13106/Jafeb.2020.Vol7.No10.443 


\section{Lampiran}

Tabel 1.

Item Pengukuran Tiap Variabel

\begin{tabular}{|c|c|}
\hline Variabel & Item \\
\hline \multirow[t]{5}{*}{ Kepemimpinan } & $\begin{array}{l}\text { Atasan memberikan dukungan moril selama } \\
\text { pandemi }\end{array}$ \\
\hline & $\begin{array}{l}\text { Atasan memberikan contoh nyata setiap } \\
\text { menyelesaikan permasalahan }\end{array}$ \\
\hline & $\begin{array}{l}\text { Atasan memberikan ruang untuk komunikasi } \\
\text { dua arah setiap saat selama pandemi. }\end{array}$ \\
\hline & $\begin{array}{l}\text { Atasan berempati kepada karyawan, jika } \\
\text { mengalami kesulitan selama pandemi. }\end{array}$ \\
\hline & $\begin{array}{l}\text { Atasan memberikan sikap, keputusan yang } \\
\text { fleksibel terhadap situasi kerja selama } \\
\text { pandemi. }\end{array}$ \\
\hline \multirow[t]{5}{*}{ Work From Home } & $\begin{array}{l}\text { Saya merasa dapat menyelesaikan } \\
\text { pekerjaan kantor di rumah. }\end{array}$ \\
\hline & $\begin{array}{l}\text { Saya merasa bekerja di rumah adalah } \\
\text { kebijakan yang tepat. }\end{array}$ \\
\hline & $\begin{array}{l}\text { Saya merasa bisa berkonsentrasi ketika } \\
\text { harus bekerja di rumah. }\end{array}$ \\
\hline & $\begin{array}{l}\text { Saya merasa bekerja di rumah adalah } \\
\text { pilihan yang tepat untuk saat sekarang. }\end{array}$ \\
\hline & $\begin{array}{l}\text { Saya dapat mengatur jam kerja selama di } \\
\text { rumah. }\end{array}$ \\
\hline \multirow[t]{5}{*}{ Dukungan Perusahaan } & $\begin{array}{l}\text { Perusahaan benar - benar peduli dengan } \\
\text { kesejahteraan saya. }\end{array}$ \\
\hline & $\begin{array}{l}\text { Perusahaan bersedia memperluas dirinya } \\
\text { untuk membantu saya melakukan pekerjaan } \\
\text { saya dengan kemampuan terbaik saya. }\end{array}$ \\
\hline & $\begin{array}{l}\text { Perusahaan akan mengabulkan permintaan } \\
\text { yang masuk akal untuk perubahan kondisi } \\
\text { kerja saya. }\end{array}$ \\
\hline & $\begin{array}{l}\text { Perusahaan akan mengerti jika saya tidak } \\
\text { dapat menyelesaikan tugas tepat waktu. }\end{array}$ \\
\hline & $\begin{array}{l}\text { Perusahaan bangga dengan prestasi saya di } \\
\text { tempat kerja. }\end{array}$ \\
\hline \multirow[t]{5}{*}{ Kinerja Karyawan } & $\begin{array}{l}\text { Saya mampu bekerja secara efektif dan } \\
\text { efisien }\end{array}$ \\
\hline & $\begin{array}{l}\text { Saya selalu berusaha mencapai target kerja } \\
\text { yang ditetapkan perusahaan. }\end{array}$ \\
\hline & $\begin{array}{l}\text { Saya frustasi dengan bagian dari pekerjaan } \\
\text { saya. }\end{array}$ \\
\hline & $\begin{array}{l}\text { Saya merasa bahwa saya mencapai kurang } \\
\text { dari semestinya. }\end{array}$ \\
\hline & $\begin{array}{l}\text { Saya merasa bahwa saya tidak mendapat } \\
\text { yang saya inginkan dari pekerjaan saya. }\end{array}$ \\
\hline
\end{tabular}

